\title{
Sorghum Grain Hardness and Its Relationship to Mold Susceptibility and Mold Resistance ${ }^{\dagger}$
}

\author{
Ramamurthi Jambunathan; Milind S. Kherdekar, and John W. Stenhouse \\ International Crops Research Institute for the Semi-Arid Tropics (ICRISAT), \\ Patancheru, Andhra Pradesh 502 324, India
}

\begin{abstract}
Sorghum [Sorghum bicolor (L.) Moench] cultivars exhibiting contrasting reactions to the grain mold complex were grown at Patancheru, India, in one postrainy (1988-1989) and two consecutive rainy seasons (1989 and 1990). Sorghum grain hardness was measured by four methods: grinding time required to obtain a fixed volume of flour from grains in a Stenvert hardness tester, force required to break the grains using Kiya and Instron food testers, and density grading in sodium nitrate solution measured as percentage of floating grains. Ergosterol concentration was determined in grains to assess the extent of mold damage. The Stenvert method was convenient and rapid and was significantly correlated with the other three methods but negatively and significantly correlated with the ergosterol concentration. Grains grown in the postrainy season exhibited higher hardness than those grown in the rainy seasons. Mold-resistant cultivars exhibited significantly greater hardness than mold-susceptible cultivars. Ergosterol concentration indicating the extent of mold attack was negatively and significantly $(P<$ $0.01)$ correlated with Stenvert hardness values in mold-resistant phenotypically white sorghum grains (without testa) in both the rainy seasons.
\end{abstract}

\section{INTRODUC'TION}

Sorghum grain hardness can be measured by different methods. Pomeranz (1986) used four indirect methodstime to grind by the Brabender microhardness tester, resistance to grinding by the Stenvert hardness tester (SHT), particle size index (PSI), and near-infrared reflectance at $1680 \mathrm{~nm}$ of ground grain samples. He reported that the SHT method was useful for rapid and reliable differentiation of 65 sorghum samples having various textures and compositions. Kirleis et al. (1984) developed a method for measuring endosperm texture by quantitatively determining the corneous and floury areas of sectioned sorghum grains using a light microscope. Hallgren and Murty (1983) proposed a simple flotation technique for measuring grain vitreousness. A tangential abrasive dehulling device has also been used for measuring sorghum grain hardness (Lawton and Faubion, 1989). Ali and Wills (1985) suggested that the time required to pearl $10 \%$ of grain could be used as an index of grain hardness. It is recognized that grain hardness is a difficult parameter to measure precisely by any one method (Kirleis and Crosby, 1982). Several grain factors are known to contribute to overall grain hardness including grain size and shape, the thickness of the pericarp, the adherence of the pericarp to the endosperm (tackiness), and starch-protein interactions (Greenwell and Schofield, 1986).

Most of the sorghum in the world is grown in the semiarid tropical regions under rainfed conditions. In these regions, often the local environmental conditions are conducive to weathering of sorghum grains, including the development of grain mold. Sorghum cultivars with resistance to grain mold therefore assume greater importance under such conditions. Rana et al. (1977) reported that tan plant type having grains with lower water absorption capacity and higher grain hardness could contribute to mold-resistant cultivars. The association of flavan-4-ols with grain mold resistance in sorghum cultivars was reported (Jambunathan et al., 1986, 1990; Jam-

'Submitted as pournal Articlo No. 1307 by ICRISAT. bunathan and Kherdekar, 1991). However, flavan-4-ols were not associated with mold resistance in sorghum grains having a white seed coat (Jambunathan et al., 1991). The presence of high tannin in sorghum has been reported to be associated with grain mold resistance (Harris and Burns, 1973). The presence of tannin in the seed (pigmented testa) is reported to be controlled by spreader gene (Hahn et al., 1984). The concentration of ergosterol in sorghum grains will give a direct measure of the biomass of organisms that cause grain mold. Therefore, it is a useful and precise index to indicate the extent of mold attack on grains (Seitz et al., 1979; Jambunathan et al., 1991). To the best of our knowledge, little is known about the hardness values of grains of mold-susceptible and mold-resistant sorghum cultivars grown in rainy and postrainy seasons. Our objective of the present study was to evaluate different methods to determine the hardness of sorghum grains and to study its interrelationship with grain mass, mold susceptibility, and mold resistance of different sorghum cultivars grown in three seasons.

\section{EXPERIMENTAL PROCEDURES}

Agronomy. Ten sorghum germplasm accessions and three breeding lines were grown during the 1988-1989 postrainy and 1989 and 1990 rainy seasons on a Vertisol at the International Crops Research Institute for the Semi-Arid Tropics (ICRISAT), Patancheru, India. They were planted in a randomized complete block design with three replications. Other details of the planting plan and agronomy were as reported earlier (Jambunathan et al., 1990) except that sprinkler irrigation was not provided in the postrainy season. The developing sorghum panicles were tagged at $50 \%$ flowering, harvested 14 days after maturity, and threshed. Grains were stored at $4^{\circ} \mathrm{C}$ before analysis.

Ergosterol. The concentration of ergosterol in sorghum grains was determined using a high-performance liquid chromatograph as described earlier (Jambunathan et al., 1991).

Grain Hardness. Grains were equilibrated to a moisture content of $6.5 \pm 1.0 \%$ before hardness determinations were made. The hardness of a single sorghum grain was determined by two methods, each using 20 randomly selected grains from each replication: (1) An Instron food testing machine (Model 1140, High Wycombe, England) with a probe of $0.75-\mathrm{cm}$ diameter was used to break the grain, and the breaking force was recorded 
Table I. Description of Sorghum Accessions and Breeding Lines, Grain Color, and Munsell Color Coding

\begin{tabular}{|c|c|c|c|}
\hline group ${ }^{a}$ & $\begin{array}{l}\text { accession/ } \\
\text { breeding line }\end{array}$ & grain color & $\begin{array}{l}\text { Munsell } \\
\text { color coding }\end{array}$ \\
\hline $\begin{array}{l}\mathrm{CRT}^{+} \text {(colored, } \\
\text { resistant } \\
\text { with testa) }\end{array}$ & $\begin{array}{l}\text { IS } 625 \\
\text { IS } 9353 \\
\text { IS } 18759\end{array}$ & $\begin{array}{l}\text { reddish brown } \\
\text { reddish brown } \\
\text { reddish brown }\end{array}$ & $\begin{array}{l}2.5 \mathrm{YR} / 3 / 3 \\
2.5 \mathrm{YR} / 4 / 4 \\
2.5 \mathrm{YR} / 3 / 4\end{array}$ \\
\hline $\begin{array}{l}\text { CST (colored, } \\
\text { susceptible, } \\
\text { without testa) }\end{array}$ & $\begin{array}{l}\text { IS } 402 \\
\text { IS } 417\end{array}$ & $\begin{array}{l}\text { reddish yellow } \\
\text { reddish yellow }\end{array}$ & $\begin{array}{l}5 \mathrm{YR} / 6 / 8 \\
5 \mathrm{YR} / 6 / 8\end{array}$ \\
\hline $\begin{array}{l}\text { CRT (colored, } \\
\text { resistant, } \\
\text { without testa) }\end{array}$ & $\begin{array}{l}\text { IS } 14375 \\
\text { IS } 14380 \\
\text { IS } 14384\end{array}$ & $\begin{array}{l}\text { red } \\
\text { red } \\
\text { red }\end{array}$ & $\begin{array}{l}2.5 \mathrm{YR} / 4 / 8 \\
2.5 \mathrm{YR} / 5 / 6 \\
2.5 \mathrm{YR} / 4 / 8\end{array}$ \\
\hline $\begin{array}{l}\text { WST+ (white, } \\
\text { susceptible, } \\
\text { with testa) }\end{array}$ & $\begin{array}{l}\text { IS } 2433 \\
\text { IS } 2516\end{array}$ & $\begin{array}{l}\text { white } \\
\text { white }\end{array}$ & $\begin{array}{l}10 \mathrm{YR} / 8 / 1 \\
10 \mathrm{YR} / 8 / 1\end{array}$ \\
\hline $\begin{array}{l}\text { WRT (white, } \\
\text { resistant, } \\
\text { without testa) }\end{array}$ & $\begin{array}{l}\text { B } 48826 \\
\text { B } 48890 \\
\text { B 48971 }\end{array}$ & $\begin{array}{l}\text { yellowish white } \\
\text { yellowish white } \\
\text { yellowish white }\end{array}$ & $\begin{array}{l}7.5 \mathrm{Y} / 9 / 2 \\
7.5 \mathrm{Y} / 8.5 / 2 \\
5 \mathrm{Y} / 9 / 2\end{array}$ \\
\hline
\end{tabular}

a Based on phenotypic grain color, reaction to mold, and presence or absence of testa. ${ }^{b}$ Munsell color coding denotes the hue (first value), color (second value), and chroma (third value), respectively. Y, yellow; YR, yellow red.

using a load cell of 50-kg capacity. The crosshead speed was set at $80 \mathrm{~mm} \mathrm{~min}^{-1}$, and the ratio of chart to crosshead movement was 2:1. The force (kilograms) required to break the grain was measured. (2) A manually operated Kiya hardness tester (Kiya Seisakusho Ltd., Japan) with a bar-type probe (0.5-cm diameter) was used with a maximum permissible load of $20 \mathrm{~kg}$ for the determination of hardness of a single grain. The grinding resistance offered by $18 \mathrm{~g}$ of sorghum grains in a micro hammer-cutter mill (Stenvert hardness tester, Glencreston, Stanmore, England) to obtain a fixed volume of flour was measured in seconds ( $\mathrm{Po}_{0}$ meranz et al., 1985).

Grain Mass and Density. One-hundred-grain mass of each of the field replications was determined after the grains were equilibrated to a constant moisture content. The same material was used for the floaters test. The method of Hallgren and Murty (1983) was employed to determine the percentage of grains floating (percent floaters) in a sodium nitrate solution of specific gravity $1.315 \mathrm{~g} \mathrm{~mL}^{-1}$. All measurements (except ergosterol) were made in duplicate in each of the field replications, and mean values are reported.

\section{RESULTS AND DISCUSSION}

The grouping of sorghum germplasm accessions and breeding materials based on their phenotypic grain color (W or $C$ ), their reaction to grain mold ( $R$ or $S$ ), the presence or absence of testa ( $\mathrm{T}^{+}$or $\mathrm{T}^{-}$), their identification numbers, and the corresponding Munsell color codings (Munsell book of color, 1989) is given in Table $I$.

Data obtained for ergosterol, grain hardness by four methods, and 100-grain mass of sorghum samples that were grown in the postrainy seasor. 1988-1989 and rainy seasons 1989 and 1990 are shown in Tables II, III, and IV, respectively. We used the Waller-Duncan $K$ ratio test (Shane et al., 1990) to determine if the mean values obtained by each method were significantly different from each other.

Postrainy Season 1988-1989. As most of the days during the postrainy season were dry, the conditions were not conducive to the development of grain mold, and this was reflected in the concentration of ergosterol. Ergosterol was not detected in the three resistant groups (except in one of the accessions in the group $\mathrm{CRT}^{+}$), and the concentrations in the susceptible groups were also low (Table II). The time taken to grind the samples by the Stenvert method varied from 6.37 to $11.98 \mathrm{~s}$ among the groups. The two resistant groups without testa (CRT and WRT $^{-}$) exhibited significantly higher values than the two susceptible groups (CST ${ }^{-}$and $\mathrm{WST}^{+}$) and the resistant group having the testa $\left(\mathrm{CRT}^{+}\right)$. The data for percentage of floaters also followed a similar pattern as $\mathrm{CRT}^{-}$and WRT groups had significantly lower values than the CST-, $\mathrm{WST}^{+}$, and $\mathrm{CRT}^{+}$groups (Table II). However, the mean values obtained for the CRT ${ }^{-}$and $\mathrm{WST}^{+}$groups by Kiya and Instron methods were not significantly different from each other. Kiya and Instron values were obtained on 20 individual grains of each sample. Sample size and the variability in values obtained on each grain could have contributed to the observed nonsignificant differences between the CRT and WST ${ }^{+}$groups. The 100 -grain mass of the $\mathrm{WST}^{+}$group was significantly higher than that of other groups and was more than 2-fold higher than that of the CRT ${ }^{+}$and $\mathrm{CRT}^{-}$groups.

Rainy Seasons 1989 and 1990. Ergosterol concentrations in the mold-susceptible grains were significantly higher than that in the mold-resistant grains in both the rainy seasons 1989 and 1990 (Tables III and IV). The ergosterol concentration in the individual germplasm accession and breeding line of resistant materials ranged from 10.1 (IS 9353, rainy season 1989) to $28.4 \mu \mathrm{g} \mathrm{g}^{-1}$ (B 48971 , rainy season 1990 ). However, in the susceptible cultivars it ranged from 71.9 (IS 417 , rainy season 1989) to $268.5 \mu \mathrm{g} \mathrm{g}^{-1}$ (IS 2433, rainy season 1990).

The Stenvert test data on samples from the rainy seasons of 1989 and 1990 (Tables III and IV) showed that grains of resistant groups took significantly longer to grind than those of the susceptible groups. However, it is noteworthy that in both seasons among the resistant groups grains of the WRT- group took longer to grind and their values were significantly higher than those of the CRT $\mathrm{T}^{+}$and CRT groups. Similarly, among the susceptible groups, grains of the CST group took longer to grind and their values were significantly higher than that of the $\mathrm{WST}^{+}$group in both seasons.

Floaters (percentage) of the $\mathrm{CST}^{-}$and $\mathrm{WST}^{+}$groups were 100 or close to 100 and were significantly higher than those of the three resistant groups $\mathrm{CRT}^{+}, \mathrm{CRT}^{2}$, and WRT ${ }^{-}$ (Tables III and IV).

The force (kilograms) to break the grain using a Kiya instrument for the $\mathrm{CST}^{-}$and $\mathrm{WST}^{+}$groups was significantly lower than those of the two resistant groups CRT and WRT' ${ }^{-}$in both 1989 and 1990 rainy seasons (Tables III and IV). Rana et al. (1977) reported a breaking strength range from 2.7 to $8.7 \mathrm{~kg}$ for sorghum grains. They suggested that a breaking strength of more than $7 \mathrm{~kg}$ could be used as one of the criteria for the selection of sorghum rultivars that could withstand grain deterioration in the rainy season. Our highest reported value for Kiya hardness test was $4.37 \mathrm{~kg}$ for the CRT group in the rainy season 1990 , which is well below their recommended value of 7 $\mathrm{kg}$, though the CRT' group exhibited grain mold-resistant characteristics.

The measurements made by using the Instron test in the rainy season 1989 were similar to those of the Kiya test (Table III) in that the values for CRT and WRT were significantly higher than those of $\mathrm{CST}^{-}$and WST ${ }^{+}$ groups. However, in the rainy season 1990 (Table IV), the Instron value obtained for the $\mathrm{WST}^{+}$group was not significantly different from those of any of the three resistant groups, $\mathrm{CRT}^{+}, \mathrm{CRT}^{2}$, and $\mathrm{WRT}^{-}$. In the rainy seasons of 1989 and 1990 , the values obtained in the Kiya and Instron tests for the CRT ${ }^{+}$group were closer to those of the susceptible groups CST ${ }^{-}$and $\mathrm{WST}^{+}$than to the resistant groups $\mathrm{CRT}^{-}$and WRT ${ }^{-}$. It is also noteworthy that among the accessions belonging to the $\mathrm{CRT}^{+}$group, 
Table II. Ercosterol Concentration, Grain Hardnese Values, and 100-Grain Mass of Mold-Resistant and Mold-Susceptible Sorghum Accessions and Breeding Lines, Postrainy Season 1988-1989

\begin{tabular}{|c|c|c|c|c|c|c|c|}
\hline \multirow[b]{2}{*}{ group } & \multirow[b]{2}{*}{$\begin{array}{l}\text { accession/ } \\
\text { breeding line }\end{array}$} & \multirow[b]{2}{*}{$\begin{array}{c}\text { ergosterol, } \\
\mu \mathrm{B} \mathrm{B} \\
\end{array}$} & \multicolumn{4}{|c|}{ grain hardness values } & \multirow[b]{2}{*}{$\begin{array}{c}\text { 100-grain } \\
\text { mass, g }\end{array}$} \\
\hline & & & $\begin{array}{c}\text { Stenvert } \\
\text { time, }{ }^{a} \mathbf{s}\end{array}$ & floaters, ${ }^{\circ} c$ & $\begin{array}{c}\text { Kiya } \\
\text { force, }^{b} \mathrm{~kg}\end{array}$ & $\begin{array}{c}\text { Instron } \\
\text { force, }{ }^{b} \mathrm{~kg}\end{array}$ & \\
\hline $\mathrm{CRT}^{+}$ & $\begin{array}{l}\text { IS } 625 \\
\text { IS } 9353 \\
\text { IS } 18759 \\
\text { mean } \\
\pm S E\end{array}$ & $\begin{array}{l}N^{r} \\
\text { ND } \\
5.4 \\
1.8 \\
1.80\end{array}$ & $\begin{array}{l}6.28 \\
7.74 \\
6.19 \\
6.74^{\star} \\
1.091\end{array}$ & $\begin{array}{c}94 \\
58 \\
99 \\
84^{c} \\
7.0\end{array}$ & $\begin{array}{l}2.27 \\
5.33 \\
2.47 \\
3.36^{\curvearrowleft} \\
0.513\end{array}$ & $\begin{array}{l}2.23 \\
3.37 \\
2.50 \\
2.70^{\circ} \\
0.201\end{array}$ & $\begin{array}{l}1.54 \\
2.31 \\
2.27 \\
2.04^{n} \\
0.137\end{array}$ \\
\hline $\mathrm{CST}^{2}$ & $\begin{array}{l}\text { IS } 402 \\
\text { IS } 417 \\
\text { mean } \\
\pm S E\end{array}$ & $\begin{array}{l}2.8 \\
\text { ND } \\
1.4 \\
1.40\end{array}$ & $\begin{array}{l}7.14 \\
8.60 \\
7.87^{b} \\
0.422\end{array}$ & $\begin{array}{l}82 \\
31 \\
57^{b} \\
11.4\end{array}$ & $\begin{array}{l}4.87 \\
6.10 \\
5.49^{b} \\
0.352\end{array}$ & $\begin{array}{l}3.57 \\
3.80 \\
3.69^{b} \\
0.182\end{array}$ & $\begin{array}{l}2.81 \\
2.93 \\
2.93^{\mathrm{c}} \\
0.072\end{array}$ \\
\hline $\mathrm{CRT}^{-}$ & $\begin{array}{l}\text { IS } 14375 \\
\text { IS } 14380 \\
\text { IS } 14384 \\
\text { mean } \\
\pm S E\end{array}$ & $\begin{array}{l}\text { ND } \\
\text { ND } \\
\text { ND }\end{array}$ & $\begin{array}{c}11.40 \\
13.00 \\
11.53 \\
11.98^{d} \\
0.389\end{array}$ & $\begin{array}{l}2 \\
2 \\
1 \\
2^{4} \\
0.5\end{array}$ & $\begin{array}{l}6.83 \\
6.37 \\
7.03 \\
6.74^{\mathrm{c}} \\
0.193\end{array}$ & $\begin{array}{l}4.43 \\
4.43 \\
4.50 \\
4.45^{b, c} \\
0.158\end{array}$ & $\begin{array}{l}2.10 \\
1.94 \\
2.12 \\
2.05^{n} \\
0.047\end{array}$ \\
\hline $\mathrm{WST}^{+}$ & $\begin{array}{l}\text { IS } 2433 \\
\text { IS } 2516 \\
\text { mean } \\
\pm S E\end{array}$ & $\begin{array}{l}10.1 \\
5.6 \\
7.9 \\
2.25\end{array}$ & $\begin{array}{l}6.24 \\
6.50 \\
6.37^{\circ} \\
0.449\end{array}$ & $\begin{array}{l}91 \\
90 \\
91^{\prime} \\
0.8\end{array}$ & $\begin{array}{l}6.33 \\
7.13 \\
6.73^{c} \\
0.208\end{array}$ & $\begin{array}{l}3.83 \\
3.83 \\
3.83^{b} \\
0.212\end{array}$ & $\begin{array}{l}4.23 \\
4.48 \\
4.36^{d} \\
0.071\end{array}$ \\
\hline WRT & $\begin{array}{l}\text { B } 48826 \\
\text { B } 48890 \\
\text { B } 48971 \\
\text { mean } \\
\pm S E\end{array}$ & $\begin{array}{l}N D \\
N D \\
N D\end{array}$ & $\begin{array}{c}11.18 \\
11.35 \\
10.33 \\
10.95^{c} \\
0.561\end{array}$ & $\begin{array}{l}1 \\
8 \\
6 \\
5^{n} \\
1.4\end{array}$ & $\begin{array}{l}7.90 \\
6.33 \\
5.70 \\
6.64^{c} \\
0.337\end{array}$ & $\begin{array}{l}5.57 \\
4.90 \\
3.13 \\
4.53 \mathrm{r} \\
0.377\end{array}$ & $\begin{array}{l}2.26 \\
2.74 \\
2.43 \\
2.48^{b} \\
0.022\end{array}$ \\
\hline
\end{tabular}

${ }^{a}$ Means of three field replications and each analyzed in duplicate except ergosterol, which was analyzed once in all replications. ${ }^{b}$ Means of three field replications and 20 determinations were made on each of the replications. Mean values having the same superscript under each column do not differ significantly from each other. " ND, not detected.

Table III. Ergosterol Concentration, Grain Hardness Values, and 100-Grain Mass of Mold-Resistant and Mold-Susceptible Sorghum Accessions and Breeding Lines, Rainy Season 1989

\begin{tabular}{|c|c|c|c|c|c|c|c|}
\hline \multirow[b]{2}{*}{ group } & \multirow[b]{2}{*}{$\begin{array}{c}\text { accession/ } \\
\text { breeding line }\end{array}$} & \multirow[b]{2}{*}{$\begin{array}{l}\text { ergosterol, }{ }^{a} \\
\qquad \mathrm{~g} \mathrm{~g} \mathrm{~g}^{-1}\end{array}$} & \multicolumn{4}{|c|}{ grain hardness values } & \multirow[b]{2}{*}{$\begin{array}{c}100-\text { grain } \\
\text { mass, } 8\end{array}$} \\
\hline & & & $\begin{array}{c}\text { Stenvert } \\
\text { time, }{ }^{a} \mathbf{8}\end{array}$ & floaters, ${ }^{a} \%$ & $\begin{array}{c}\text { Kiya } \\
\text { force, }^{b} \mathrm{~kg}\end{array}$ & $\begin{array}{c}\text { Instron } \\
\text { force, }^{b} \mathrm{~kg}\end{array}$ & \\
\hline $\mathrm{CRT}^{+}$ & $\begin{array}{l}\text { IS } 625 \\
\text { IS } 9353 \\
\text { IS } 18759 \\
\text { mean } \\
\pm \text { SE }\end{array}$ & $\begin{array}{c}18.8 \\
10.1 \\
17.4 \\
15.4^{\natural} \\
1.93\end{array}$ & $\begin{array}{l}5.30 \\
6.67 \\
6.85 \\
6.27 \mathrm{c} \\
0.631\end{array}$ & $\begin{array}{c}98 \\
77 \\
98 \\
91^{\mathrm{b}} \\
4.5\end{array}$ & $\begin{array}{l}1.79 \\
3.52 \\
2.45 \\
2.59 \mathrm{~b} \\
0.283\end{array}$ & $\begin{array}{l}1.76 \\
2.12 \\
2.08 \\
1.99 \\
0.079\end{array}$ & $\begin{array}{l}1.27 \\
1.96 \\
2.08 \\
1.77 a, b \\
0.132\end{array}$ \\
\hline $\mathrm{CST}^{-}$ & $\begin{array}{l}\text { IS } 402 \\
\text { IS } 417 \\
\text { mean } \\
\pm S E\end{array}$ & $\begin{array}{c}108.8 \\
71.9 \\
90.4^{\mathrm{b}} \\
12.32\end{array}$ & $\begin{array}{l}5.43 \\
4.92 \\
5.18^{\mathrm{b}} \\
0.509\end{array}$ & $\begin{array}{l}96 \\
95 \\
96^{\text {c.d }} \\
1.38\end{array}$ & $\begin{array}{l}1.72 \\
1.62 \\
1.67 \\
0.088\end{array}$ & $\begin{array}{l}1.94 \\
1.86 \\
1.91 . \\
0.048\end{array}$ & $\begin{array}{l}2.33 \\
2.05 \\
2.19 c \\
0.072\end{array}$ \\
\hline $\mathrm{CRT}^{-}$ & $\begin{array}{l}\text { IS } 14375 \\
\text { IS } 14380 \\
\text { IS } 14384 \\
\text { mean } \\
\pm S E\end{array}$ & $\begin{array}{r}21.0 \\
20.3 \\
20.6 \\
20.6^{a} \\
2.57\end{array}$ & $\begin{array}{l}5.77 \\
7.13 \\
6.28 \\
6.39 \\
0.538\end{array}$ & $\begin{array}{l}53 \\
42 \\
41 \\
45^{a} \\
3.83\end{array}$ & $\begin{array}{l}4.15 \\
4.14 \\
4.43 \\
4.24^{c} \\
0.181\end{array}$ & $\begin{array}{l}2.59 \\
2.60 \\
2.74 \\
2.64^{b} \\
0.044\end{array}$ & $\begin{array}{l}1.59 \\
1.59 \\
1.71 \\
1.63^{\circ} \\
0.019\end{array}$ \\
\hline WST $^{+}$ & $\begin{array}{l}\text { IS } 2433 \\
\text { IS } 2516 \\
\text { mean } \\
\pm S E\end{array}$ & $\begin{array}{r}114.7 \\
89.2 \\
102.0^{\mathrm{b}} \\
14.14\end{array}$ & $\begin{array}{l}4.20 \\
4.16 \\
4.18^{a} \\
0.364\end{array}$ & $\begin{array}{l}100 \\
100 \\
100^{d} \\
0.15\end{array}$ & $\begin{array}{l}1.71 \\
1.84 \\
1.78^{a, b} \\
0.259\end{array}$ & $\begin{array}{l}1.96 \\
1.91 \\
1.94^{\circ} \\
0.184\end{array}$ & $\begin{array}{l}2.71 \\
3.23 \\
2.97 d \\
0.082\end{array}$ \\
\hline WRT & $\begin{array}{l}\text { B } 48826 \\
\text { B } 48890 \\
\text { B } 48971 \\
\text { mean } \\
\pm \text { SE }\end{array}$ & $\begin{array}{c}10.2 \\
17.1 \\
15.6 \\
14.3^{\circ} \\
1.49\end{array}$ & $\begin{array}{l}8.36 \\
8.44 \\
7.87 \\
8.22^{d} \\
1.142\end{array}$ & $\begin{array}{l}44 \\
60 \\
47 \\
50^{\circ} \\
3.45\end{array}$ & $\begin{array}{l}5.17 \\
3.78 \\
3.72 \\
4.22 \\
0.261\end{array}$ & $\begin{array}{l}3.62 \\
2.55 \\
2.49 \\
2.89 \mathrm{~b} \\
0.186\end{array}$ & $\begin{array}{l}1.64 \\
2.05 \\
1.75 \\
1.81^{b} \\
0.356\end{array}$ \\
\hline
\end{tabular}

a Means of three field replications and each analyzed in duplicate except ergosterol, which was analyzed once in all replications. ${ }^{b}$ Means of three field replications and 20 determinations were made on each of the replications. Mean values having the same superscript under each column do not differ significantly from each other.

the data obtained for IS 9353 were similar to those for the accessions and breeding materials belonging to the two resistant groups CRT ${ }^{-}$and WRT'. Therefore, the grain quality characteristics of accessions belonging to the $\mathrm{CRT}^{+}$ group need further investigation to explain the role of testa and other factors in these measurements. The 100- grain mass data of both the rainy seasons of 1989 and 1990 showed that the grains of the WST ${ }^{+}$group exhibited the highest mass. Grains of the CRT group exhibited the lowest mass in both the seasons (Tables III and IV).

The data shown in Tables II-IV indicate that the measurements in the postrainy season differed markedly 
Table IV. Ergosterol Concentration, Grain Hardness Values, and 100-Grain Mass of Mold-Resietant and Mold-Busceptible Sorghum Accessions and Breeding Lines, Rainy Season 1990

\begin{tabular}{|c|c|c|c|c|c|c|c|}
\hline \multirow[b]{2}{*}{ group } & \multirow{2}{*}{$\begin{array}{c}\text { accession/ } \\
\text { breeding line }\end{array}$} & \multirow[b]{2}{*}{ ergosterol, ${ }^{a} \mu \mathrm{g} \mathbf{g}^{-1}$} & \multicolumn{4}{|c|}{ grain hardness values } & \multirow[b]{2}{*}{ 100-grain mass, $\mathrm{g}$} \\
\hline & & & Stenvert time, ${ }^{a} \mathrm{~B}$ & floaters, ${ }^{a} \%$ & Kiya force, ${ }^{b} \mathbf{k g}$ & Instron force, ${ }^{b} \mathrm{~kg}_{\mathrm{g}}$ & \\
\hline $\mathrm{CRT}^{+}$ & $\begin{array}{l}\text { IS } 625 \\
\text { IS } 9353 \\
\text { IS } 18759 \\
\text { mean } \\
\pm S E\end{array}$ & $\begin{array}{c}18.0 \\
16.0 \\
13.6 \\
15.9^{9} \\
1.29\end{array}$ & $\begin{array}{l}6.92 \\
6.96 \\
5.70 \\
6.53^{c} \\
0.331\end{array}$ & $\begin{array}{c}98 \\
79 \\
100 \\
92^{\mathrm{c}} \\
2.57\end{array}$ & $\begin{array}{l}2.83 \\
4.93 \\
2.83 \\
3.53^{\mathrm{b}} \\
0.357\end{array}$ & $\begin{array}{l}2.16 \\
2.33 \\
2.02 \\
2.17^{b} \\
0.102\end{array}$ & $\begin{array}{l}1.54 \\
2.04 \\
2.17 \\
1.92^{\mathrm{b}} \\
0.101\end{array}$ \\
\hline $\mathrm{CST}^{-}$ & $\begin{array}{l}\text { IS } 402 \\
\text { IS } 417 \\
\text { mean } \\
\pm S E\end{array}$ & $\begin{array}{c}107.8 \\
73.7 \\
90.8^{\mathrm{b}} \\
14.62\end{array}$ & $\begin{array}{l}5.24 \\
5.29 \\
5.27^{b} \\
0.149\end{array}$ & $\begin{array}{l}100 \\
100 \\
100^{d} \\
0.19\end{array}$ & $\begin{array}{l}2.43 \\
2.43 \\
2.43^{n} \\
0.043\end{array}$ & $\begin{array}{l}1.52 \\
1.83 \\
1.68^{\bullet} \\
0.091\end{array}$ & $\begin{array}{l}2.13 \\
2.13 \\
2.13^{\mathrm{c}} \\
0.112\end{array}$ \\
\hline CRT & $\begin{array}{l}\text { IS } 14375 \\
\text { IS } 14380 \\
\text { IS } 14384 \\
\text { mean } \\
\pm S E\end{array}$ & $\begin{array}{r}25.8 \\
23.8 \\
28.0 \\
25.9^{a} \\
2.53\end{array}$ & $\begin{array}{l}6.68 \\
6.74 \\
6.34 \\
6.59^{c} \\
0.249\end{array}$ & $\begin{array}{l}48 \\
41 \\
49 \\
46^{\bullet} \\
2.54\end{array}$ & $\begin{array}{l}4.30 \\
4.20 \\
4.60 \\
4.37^{\mathrm{c}} \\
0.14\end{array}$ & $\begin{array}{l}2.50 \\
2.44 \\
2.44 \\
2.50^{c} \\
0.122\end{array}$ & $\begin{array}{l}1.63 \\
1.67 \\
1.67 \\
1.65^{\star} \\
0.012\end{array}$ \\
\hline $\mathrm{WST}^{+}$ & $\begin{array}{l}\text { IS } 2433 \\
\text { IS } 2516 \\
\text { mean } \\
\pm S E\end{array}$ & $\begin{array}{r}268.5 \\
127.3 \\
197.9^{\mathrm{c}} \\
34.60\end{array}$ & $\begin{array}{l}4.23 \\
4.59 \\
4.41^{\mathrm{a}} \\
0.712\end{array}$ & $\begin{array}{l}100 \\
100 \\
100^{d} \\
0.0\end{array}$ & $\begin{array}{l}2.03 \\
2.33 \\
2.18^{\mathrm{a}} \\
0.122\end{array}$ & $\begin{array}{l}2.19 \\
2.41 \\
2.30^{\text {b.c }} \\
0.072\end{array}$ & $\begin{array}{l}2.81 \\
3.43 \\
3.12^{\mathrm{d}} \\
0.019\end{array}$ \\
\hline WRT & $\begin{array}{l}\text { B } 48826 \\
\text { B } 48890 \\
\text { B 48971 } \\
\text { mean } \\
\pm S E\end{array}$ & $\begin{array}{r}22.0 \\
23.8 \\
28.4 \\
24.7^{\text {a }} \\
1.77\end{array}$ & $\begin{array}{l}7.51 \\
7.68 \\
7.34 \\
7.51^{\mathrm{d}} \\
0.319\end{array}$ & $\begin{array}{l}76 \\
93 \\
60 \\
76^{b} \\
3.55\end{array}$ & $\begin{array}{l}3.63 \\
3.77 \\
3.90 \\
3.77^{b} \\
0.118\end{array}$ & $\begin{array}{l}2.52 \\
2.69 \\
2.36 \\
2.52^{c} \\
0.084\end{array}$ & $\begin{array}{l}1.98 \\
2.15 \\
1.82 \\
1.98 \mathrm{~b} \\
0.058\end{array}$ \\
\hline
\end{tabular}

- Means of three field replications and each analyzed in duplicate except ergosterol, which was analyzed once in all replications. ${ }^{b}$ Means of three field replications and 20 determinations were made on each of the replications. Mean values having the same superscript under each column do not differ significantly from each other.

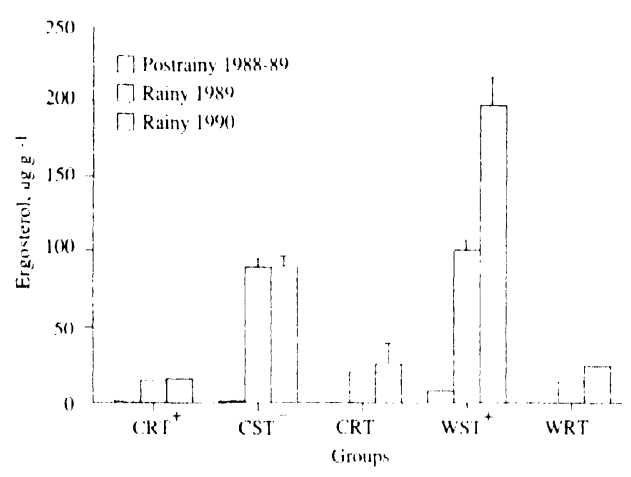

Figure 1. Concentration of ergosterol in grains of moldsusceptible and mold-resistant sorghum accessions and breeding materials that were grown in postrainy and rainy seasons. (Standard error values of less than 3.0 are not shown.)

from those in the rainy seasons. For example, the highest ergosterol content in the postrainy season 1988-1989 was $10.1 \mathrm{\mu g} \mathrm{g}^{-1}$ in IS 2433 (WST $^{+}$group, Table II), while the lowest ergosterol concentration in the rainy season was $10.1 \mu \mathrm{g} \mathrm{g}^{-1}$ in IS 9353 (CRT $^{+}$group, Table III). Similar comparisons can be made to stress that the data obtained on mold-resistant and mold-susceptible sorghum in the rainy season would be quite different from the data obtained in the postrainy season. A comparison of the data obtained in the three seasons can be made from Figures 1-6. Data obtained on germplasm accessions and breeding lines belonging to mold-susceptible and moldresistant groups clearly showed that the ergosterol values obtained for the resistant groups $\mathrm{CRT}^{+}, \mathrm{CRT}^{-}$, and WRTwere significantly different (with a few exceptions as described above) from those of the susceptible groups CST and WST+ (Figure 1). Grains of CRT ${ }^{+}$and WRT from the postrainy season took longer to grind than that of $\mathrm{CRT}^{+}$group (Figure 2). This could be due to the presence of tannin in the $\mathrm{CRT}^{+}$group. Among the three resistant

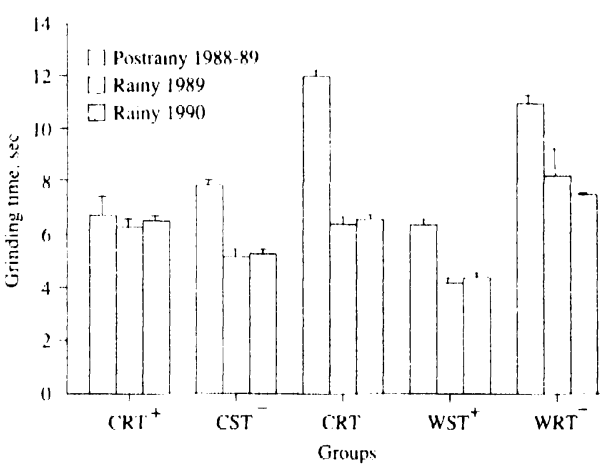

Figure 2. Time (seconds) taken to grind $18 \mathrm{~g}$ of grains of moldsusceptible and mold-resistant sorghum accessions and breeding materials that were grown in postrainy and rainy seasons.

$$
\begin{aligned}
& \text { 17] Postratny } 1988.89 \\
& \square \text { Rainy } 1989 \\
& \text { [j] Rann 1990 } \\
& \begin{array}{c}
100 \\
80 \\
60 \\
\frac{5}{5} \\
40
\end{array} \\
& 20+ \\
& \begin{array}{lllll}
\mathrm{CRT}^{+} & \mathrm{CST} & \mathrm{CRT} & \mathrm{WST}^{*} & \text { WRT }
\end{array}
\end{aligned}
$$

Figure 3. Percentage of floating grains in mold-susceptible and mold-resistant sorghum accessions and breeding materials that were grown in postrainy and rainy seasons. (Standard error values of less than 3.0 are not shown.)

groups, $\mathrm{CRT}^{+}, \mathrm{CRT}^{-}$, and WRT', the floaters value obtained for the $\mathrm{CRT}^{+}$group (accessions that are colored and mold-resistant and have the testa) was closer to that 


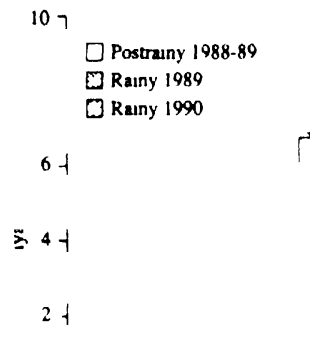$$
\mathrm{CRT}^{+} \mathrm{CST}^{-} \underset{\mathrm{GRT}}{\mathrm{CRT}^{-}} \mathrm{WST}^{+} \quad \mathrm{WRT}^{-}
$$

Figure 4. Force (kilograms) required to break the grain using Kiya hardness tester of mold-susceptible and mold-resistant sorghum accessions and breeding materials that were grown in postrainy and rainy seasons. (Standard error values of less than 0.2 are not shown.)

107

$$
\begin{aligned}
& \square \text { Postrany } 1988-89 \\
& \text { Q Ranny } 1989 \\
& \text { ○ Rainy } 1990
\end{aligned}
$$

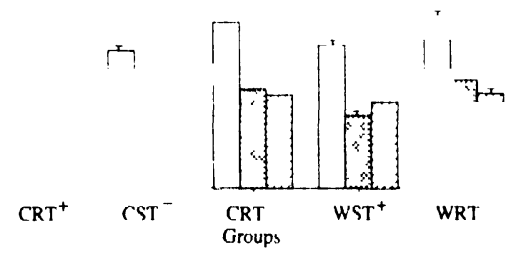

Figure 5. Force (kilograms) required to break the grain using Instron food tester of mold-susceptible and mold-resistant sorghum accessions and breeding materials that were grown in postrainy and rainy seasons. (Standard error values of less than 0.2 are not shown.)

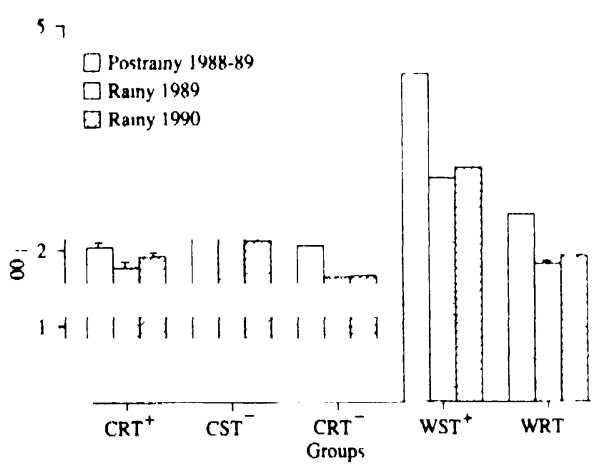

Figure 6. 100-Grain mass of mold-susceptible and mold-resistant sorghum accessions and breeding materials that were grown in postrainy and rainy seasons. (Standard error values of less than 0.1 are not shown.)

of the two susceptible groups, CST ${ }^{-}$and $\mathrm{WST}^{+}$, than to that of the two resistant groups, CRT and WRT (Figure 3). Kiys and Instron values were higher for the postrainy samples and similar for both the rainy seasons for individual groups (Figures 4 and 5 ). The variability for 100-grain mass is shown in Figure 6.

Grain mold resistance in the groups $\mathrm{CRT}^{+}$and $\mathrm{CRT}^{-}$ could be explained on the basis of association of flavan4-ols in these accessions (Jambunathan et al., 1990). Another reason could be due to their relatively higher hardness than those of the susceptible accessions. Floaters percentage value obtained for the $\mathrm{CRT}^{+}$group was 2-fold or higher than that of the CRT group in all three seasons.
Table V. Correlation Coefficionts among Four Hardness

\begin{tabular}{|c|c|c|c|c|c|}
\hline & Instron & Kıya & foaters & $\begin{array}{c}\text { grain } \\
\text { mass }\end{array}$ & $\begin{array}{c}\text { Sten- } \\
\text { vert }\end{array}$ \\
\hline \multicolumn{6}{|l|}{ Kıya } \\
\hline 1988-1989 postrainy & $0.82^{b}$ & & & & \\
\hline 1989 rainy & $070^{b}$ & & & & \\
\hline 1990 rainy & $041^{b}$ & & & & \\
\hline \multicolumn{6}{|l|}{ floaters } \\
\hline 1988-1989 postrainy & $-0.63^{b}$ & $-0.59^{b}$ & & & \\
\hline 1989 rainy & $-0.49^{b}$ & $-0.88^{b}$ & & & \\
\hline 1990 rainy & 039 & $-078^{b}$ & & & \\
\hline \multicolumn{6}{|l|}{ grain mass } \\
\hline 1988-1989 postrainy & 0.09 & $035^{r}$ & $0.43^{b}$ & & \\
\hline 1989 rainy & $-0.42^{b}$ & $0.61^{b}$ & $0.57^{b}$ & & \\
\hline 1990 rainy & $0.55^{b}$ & $-0.54^{b}$ & $0.58^{b}$ & & \\
\hline \multicolumn{6}{|l|}{ Stenvert } \\
\hline 1988-1989 postrainy & $0.68^{b}$ & $0.53^{b}$ & $-093^{b}$ & $-0.44^{b}$ & \\
\hline 1989 rainy & $0.49^{b}$ & $0.49^{b}$ & $-0.49^{b}$ & $-0.49^{b}$ & \\
\hline 1990 rainy & $0.48^{b}$ & $0.66^{b}$ & $-0.43^{b}$ & $-0.38^{b}$ & \\
\hline \multicolumn{6}{|l|}{ ergosterol } \\
\hline $1988-1989 p$ & & & & & \\
\hline 1989 rainy & $-0.51^{\mathrm{h}}$ & $-0.70^{b}$ & $0.60^{b}$ & $0.68^{b}$ & $-0.55^{b}$ \\
\hline 1990 rainy & -0.16 & $-0.63^{b}$ & $042^{b}$ & $0.35^{r}$ & $-0.78^{b}$ \\
\hline
\end{tabular}
Tests Performed on Sorchum Grain Samples from Throe Seasons

a Correlation data not shown as majority of samples did not show the presence of ergosterol "Significant at 1 "' probability level. ' Sig. nificant at 5\% probability level.

Mold resistance therefore could possibly be explained on the basis of the presence of tannin in the CRT ${ }^{+}$group. However, the mold-resistant nature of breeding materials belonging to the WRT ${ }^{-}$group cannot be attributed to the association of flavan-4-ols or tannin as they are not detected in these samples (Jambunathan et al., 1991). However, these grains have exhibited significantly higher hardness values, even higher than those of the accessions belonging to the $\mathrm{CRT}^{+}$and CRT groups. Therefore, it would be reasonable to conclude that the grain mold-resistant nature in the breeding materials belonging to the WRT group (white sorghum, resistant to mold, without the testa) is due to the associated grain hardness in these materials. This would indicate another mechanism for explaining the grain mold resistance in sorghum cultivars.

We obtained further evidence recently in support of this hypothesis from the hardness data obtained on many landraces that were collected from Orissa, India. All of the accessions were of white grain type and relatively mold free through the rainy season in Orissa, and their hardness values (SHT) were either equal to or higher than those obtained for the WRT group repnrted here (unpublished data). We have also obtained additional data, though preliminary in nature, that could support the hypothesis that grain hardness is related to the incidence of sorghum grain mold. We grew the germplasm accession IS 402 in a pot in a glass house during the rainy season of 1988 , and grains were analyzed for ergosterol and hardness. The following values were obtained: ergosterol, $1.9 \mu \mathrm{g} \mathrm{g}^{-1}$; Stenvert time, $11.65 \mathrm{~s}$; floaters, $83 \%$; Kiya force, $6.02 \mathrm{~kg}$; Instron force, $3.43 \mathrm{~kg} ; 100$-grain mass, $3.10 \mathrm{~g}$. Data obtained for IS 402 indicated that the hardness values obtained would make it suitable to be included along with the three resistant groups. Therefore, environmental and genotypic interactions in the field would play an important role in these observations. In the case of IS 402, the incidence of grain mold could have changed the grain structure to make it softer than in the case of resistant type.

Correlations. The correlation coefficients obtained among the four methods and 100-grain mass for the data obtained in the 1988-1989 postrainy and 1989 and 1990 rainy seasons are shown in Table V. All but two of the correlation coefficients were significant for the measure- 
ments reported. Among them, all except three showed significance at the $1 \%$ probability level. Pomeranz (1986) reported no significant correlation between PSI and Brabender microhardness tester methods and between PSI and near-infrared reflectance of ground sample when they were used for indirect determination of sorghum grain hardness. However, Pomeranz (1986) observed the highest correlation between the near-infrared reflectance method and Stenvert hardness tester and concluded that the Stenvert hardness tester method was useful for rapid and reliable differentiation among 65 sorghum samples differing widely in texture and composition. Another important factor is the environment and genotypic interactions and their effect on these values. It may be seen that ergosterol concentration was significantly and negatively correlated with Stenvert data in both of the rainy seasons (Table V). This clearly shows the association of grain hardness with mold resistance. The Stenvert method is rapid and easy to perform and represents the values obtained on a relatively larger sample size among the four methods that were used in our study. Therefore, we would consider it the best among the four methods tested and agree with the observation of Pomeranz (1986). Another interesting observation was the positive association of grain mass with ergosterol concentration and the negative association of grain mass with Stenvert data. The values obtained for Instron, floaters, and Stenvert methods and grain mass on 1988-1989 postrainy sorghum grain samples were significantly correlated with the values obtained on grains from 1989 and 1990 rainy seasons. This indicates the possible usefulness of these methods in evaluating the sorghum cultivars grown in the postrainy season. In the absence of association of flavan-4-ols and tannin with mold resistance in the $\mathrm{WRT}^{+}$group, it was of interest to compare the hardness values obtained by the four methods across the three seasons. The correlation coefficients were calculated between $1988-1989$ postrainy season and rainy season 1989 , between $1988-1989$ postrainy season and rainy season 1990, and between rainy season 1989 and rainy season 1990. The minimum correlation coefficient for any of the methods tested in this way was $r=0.74(P<0.01)$ for the Instron method and the maximum correlation coefficient was $r=0.99(P<0.01)$ for the Stenvert method. The validity and robustness of the relationships described above have to be tested further in a breeding program engaged in developing mold-resistant genotypes.

Conclusions. Ergosterol concentration and hardness data obtained on mold-resistant and mold-susceptible accessions and breeding materials that were grown in the postrainy and rainy seasons shn"'ed that grain hardness is associated with grain mold resistance. During the postrainy season, the mold damage was minimal due to the local semiarid environmental conditions. The ergosterol concentration was therefore negligible and the corresponding hardness values were higher than those for the rainy season. The grain hardness values were significantly and negatively related to the ergosterol concentration and therefore can be used as an indicator of grain mold resistance. This is in addition to the earlier observation that flavan-4-ols are associated with grain mold resistance. Data obtained for one postrainy and two rainy seasons for Stenvert, floaters, and Instron methods and grain mass were significantly correlated with each other. These observations would help in making progress in breeding sorghum for grain mold resistance in the semiarid tropical regions where this disease seriously affects the productivity of sorghum.

\section{ACKNOWLEDGMENT}

We thank Y. L. Nene for his suggestions and interest. We thank V. Subramanian for helpful discussions and B. J. Moss for technical assistance.

\section{LITERATURE CITED}

Ali, M. R.; Wills, R. B. H. Grain quality and milling properties of weather-damaged sorghum. Food Technol. Aust. 1985, 37, 202-203.

Greenwell, P.; Schofield, J. D. A starch granule protein associated with endosperm softness in wheat. Cereal Chem. 1986, 63, $379-380$.

Hahn, D. H.; Rooney, L. W.; Earp, C. F. Tannins and phenols of sorghum. Cereal Foods World 1984, 29, 776-779.

Hallgren, L.; Murty, D. S. A screening test for grain hardness in sorghum employing density grading in sodium nitrate solution. J. Cereal Sci. 1983, 1, 265-274.

Harris, H. B.; Burns, R. E. Relationship between tannin content of sorghum grain and preharvest seed molding. Agron.J.1973, $65,957-959$.

Jambunathan, R.; Kherdekar, M. S. Flavan-4-ols in leaf tissues of grain mold-susceptible and mold-resistant sorghum plants at different stages of leaf development. J.Agric. Food Chem. 1991, 39, 1163-1165.

Jambunathan, R.; Butler, L. G.; Bandyopadhyay, R.; Mughogho, I. K. Polyphenol concentration in grain, leaf, and callus tissues of mold-susceptible and mold-resistant sorghum cultivars. $J$. Agric. Food Chem. 1986, 34, 425-429.

Jambunathan, R.; Kherdekar, M.S.; Bandyopadhyay, R. Flavan4-ols concentration in mold-susceptible and mold-resistant sorghum at different stages of grain development. J. Agric. Food Chem. 1990, 38, 545-548.

Jambunathan, R.; Kherdekar, M. S.; Vaidya, P. Ergosterol concentration in mold-susceptible and mold-resistant sorghum at different stages of grain development and its relationship to flavan-4-ols. J. Agric. Food Chem. 1991, 39, 1866-1870.

Kirleis, A. W.; Crosby, K. D. Sorghum hardness: Comparison of methods for its evaluation. In Proceedings of the International Symposium on sorghum grain quality, Oct 28-31 1981, Patancheru, AP, India; ICRISAT: Patancheru, 1982; pp 231241.

Kirleis, A. W.; Crosby, K. D.; Housley, T. L. A method for quantitatively measuring vitreous endosperm area in sectioned sorghum grain. Cereal Chem. 1984, 61, 556-558.

Lawton, J. W.; Faubion, J. M. Measuring kernel hardness using the tangential abrasive dehulling device. Cereal Chem. 1989, $66,519-524$.

Munseli book of color; Macbeth and Photometry Division of Hollmorgen: Baltimore, MD, 1989.

Pomeranz, Y. Comparison of screening methods for indirect determination of sorghum hardness. Cereal Chem. 1986, 63, 36-38.

Pomeranz, Y.; Czuchajowska, Z.; Martin, C. R.; Lai, F. S. Determination of corn hardness by the Stenvert hardness tester. Cereal Chem. 1985, 62, 108-112.

Rana, B. S.; Jaya Mohan Rao, V.; Tripathi, D. P.; Rao, N. G. P. Genetic analysis of exotic $x$ Indian crosses in sorghum XVII: Resistance to grain deterioration. Indian J. Genet. Plant Breed. 1977, 37, 480-487.

Seitz, L. M.; Saur, D. B.; Burroughs, R.; Mohr, H. E.; Hubbard, J. D. Ergosterol as a measure of fungal growth. Phytopathology 1979, 69, 1202-1203.

Shane, W. W.; Joyner, T. G.; Powell, C. C. APPLICAL, RANDOMA and MULTSTAT-Three microcomputer utilities for managing field trial experiments. Plant Dis. 1990, 74, 333334.

Received for review January 21, 1992. Accepted April 13, 1992. 